\title{
Demolish or Refurbish - Environmental Benefits of Housing Conservation
}

Grace Ding, (University of Technology Sydney, Australia)

\begin{abstract}
Climate change and energy efficiency are some of the most pressing issues facing China today. With its economic growth since 1978, the government has struggled to contain environmental damages and social unrest related to the economy's rapid transformation. With the rapid growth in population and urbanization the demand for housing has escalated and traditional housing has been under threat of demolition to make way for new construction. Traditional housing is generally considered wasteful in its use of land and/or energy, and is often demolished for more intensive and more energy-efficient housing, despite the resulting loss of embodied energy and urban amenity. A research project was undertaken to study the environmental performance of traditional housing in Hangzhou. The project looks into analyzing and comparing embodied energy and $\mathrm{CO}_{2}$ for seven dwellings. In addition indoor climate data were recorded and collected in the form of hourly temperature and humidity readings for one year in six local houses and in a modern unit as a control for one year. The research results reveal that there is little difference in environmental performance between traditional and conventional modern construction and the value of conservation rather than demolition as a strategic development for the construction industry.
\end{abstract}

Keywords: Embodied energy, $\mathrm{CO}_{2}$ emission, Historic buildings, Indoor climate

\section{Introduction}

Over the past decades, many countries have attempted to reduce energy consumption to mitigate the impact of global climate change. Some have proposed demolishing historic buildings because of their supposed deficiencies in environmental performance. However, an alternative view is that many historic buildings have the potential for sound environmental performance, and that retaining and upgrading them produces better results not only for energy use but also for social and cultural well-being (Power 2008).

Historic buildings are important assets as part of humanity's cultural capital; they record historical development, social and economic advancement, scientific progress, collective memory, and culture-history (Silberman 2011). Silberman (2011) goes on to state that heritage can be a driver of local and regional development, and can also be a challenge of poverty reduction and to serve to rejuvenate declining communities and heal serious social fractures. Although the conservation movement worldwide has helped to preserve some historic buildings, many are still under threat. There are claims that such buildings are old-fashioned, expensive to maintain, offer poor user comfort and are energy inefficient.

A research project was undertaken in 2010/11 in conjunction with Zhejiang University to study the environmental performance of traditional housing in Xiao He Zhi Jie, Hangzhou. The research involved an analysis of the embodied energy and $\mathrm{CO}_{2}$ content of these dwellings. Indoor climate was examined using temperature and humidity monitors in six local dwellings and also a modern unit in a nearby multi-storey building as a control. Hourly readings were 
recorded over a full annual climate cycle. The paper presents the results of the research structured in three parts. Firstly, the study reviews the literature on the environmental value of historic buildings. Secondly, background information of the project, research method and data collection are presented, followed by data analysis and discussion of the research findings.

\section{Environmental Value of Historic Buildings}

\section{Refurbish or Demolish}

Building green has become a standard building practice in the construction industry nowadays. Demolishing an inefficient property may seem to be the best way of reducing energy use and to make way for new buildings, as it is often expensive to upgrade and difficult to refurbish old houses to meet sustainability standards (Boardman et al. 2005). A key foundation of this argument is that greenhouse gas (GHG) emissions of highly efficient new housing can be far lower than that of houses built in the past due to effective use of insulation and technologies. This is the underlying premise of the argument supporting the 40 Percent House Project in advocating the demolition of a total of 3.2 million houses from 2005 to 2050 in the UK (Boardman et al. 2005; Power 2008). Demolishing houses built in the past is considered to be a way to improve environmental efficiency.

With increasing recognition that green buildings outperform conventional buildings in terms of environmental, social and economic considerations, much less is known about how green building initiatives might be incorporated into historic buildings and little work has been done to examine how they could be maintained and refurbished for sustainability. If the challenges of climate change and reduced GHG emissions are to be successfully tackled, there is potentially enormous benefit to be gained from maintain and refurbishing the historic building stocks in order to make the current built environment more environmentally-friendly and energy efficient (Bromley, Tallon \&Thomas 2005; Bullen 2007). The historic building stock has the greatest potential to lower the environmental load of the built environment significantly within the next 20 or 30 years (Bullen 2007). Mickaityte et al. (2008) in developing a conceptual model for sustainable building refurbishment suggests that sustainable maintenance and refurbishment of historic buildings uses $23 \%$ less energy than new construction. Moe (2007) further suggests that it will take approximately 65 years for a green and energy-efficient building to recover the energy and resources lost in the demolition of an historic building, even if $40 \%$ of the building materials from the demolition are recycled. Power (2008) further states that building, demolition and renovation waste make up about one-third of all landfill that is detrimental to the environment. Consequently, sustainable maintenance and refurbishment of historic buildings may be a more practical way to respond to climate change and other negative impacts on the environment.

There has been research into the environmental value of historic housing and results have demonstrated that the maintenance and conservation of historic housing stocks help to achieve environmental gains as these buildings represent a major investment in natural and human resources (Sustainable Development Commission 2006; Ireland 2008). A research project undertaken by the Empty Homes Agency, UK, reveals that refurbishing historic homes can save up to 35 tonnes of $\mathrm{CO}_{2}$ per property by removing the need for the energy locked into new build materials and construction (Ireland 2008). The research also reveals that in UK there is not much difference in terms of performance between new built and refurbished housing over an operating period of 50 years (Ireland 2008).

Research undertaken by the UK Government reveals that the energy produced from nonrenewable sources consumed in building accounts for about half of the UK's emission of carbon dioxide (Cabinet Office 2000). Over $90 \%$ of non-energy minerals used are needed to supply the

Ding G (2013) 'Demolish or refurbish - Environmental benefits of housing conservation', Australasian Journal of Construction Economics and Building, 13 (2) 18-34 
construction industry with materials. However, each year, about 70 million tons of construction and demolition materials end up as waste landfill. It is questionable whether the decision to demolish is justified for its energy-efficiency, given that the energy performance of renovated homes can improve significantly over time (Sustainable Development Commission 2006; Ireland 2008). According to Power (2008), upgrading historic housing stocks can reduce both carbon emissions and the environmental impact of new building through implementing basic energyefficiency improvement measures including insulation, double glazing, damp-proofing and condensing boilers for heating and hot water.

Despite the increasing recognition of the value of sustainable refurbishment of historic housings, there is still strong opposition to upgrade them due to economic constraints and the difficulty in matching the sustainable performance of a new house (Jackson \& Judson 2011). Despite this, however, there is strong evidence that historic housing stocks have the greatest potential to lower the environmental load of the built environment significantly over the next few decades (Jackson \& Judson 2011). The time necessary to convert a building as opposed to building new will have an impact and refurbishing a building will take less time than demolition, site clearance and new build, unless extensive structural alterations or repairs are required. According to some research the cost of refurbishing is generally much less than the cost of new construction, since many of the building elements are already constructed (Sustainable Development Commission 2006). The opposition to refurbishment is further intensified by the lack of reliable data and methodology to undertake life cycle economic, energy and environmental analysis of building elements, materials and equipment for sustainable maintenance and refurbishment of historic buildings. Little work in fact has been done in these areas. Sustainable maintenance and refurbishment of buildings involves identifying building elements/components that may require regular maintenance, repair and scheduled renovation and their related life expectancy to determine the maintenance cycle over the useful life of the building. However there is a shortage of appropriate, relevant, historical information and data that can be used.

\section{Residential Development and Energy Consumption}

Due to economic growth since the Open Door Policy in 1986, the construction industry in China has made significant progress in the last ten years. Many buildings and infrastructur projects have been required to cope with the growth of economic activities. The increased construction activities have put a vast pressure on resource and energy consumption, and related environmental issues. Currently China's energy consumption accounts for $20.6 \%$ of the global total with 4.6 tonnes $\mathrm{CO}_{2}$ emission per capita, exceeding the global median value ( $\mathrm{Li} \&$ Yao 2012).

With the rapid growth of population and urbanization, China's residential market has grown tremendously in recent years (Yang \& Kohler 2008; Li \& Yao 2012). The International Energy Agency (2009) has estimated that approximately 800 million $\mathrm{m}^{2}$ of new residential floor space will be built per annum in the next decade. However there has been little research regarding materials and energy consumption in the current and future Chinese construction industry. One of very few studies is Chen and Zhang (2005) who analyzed material input and output flow of construction and demolition material for residential buildings in Beijing. The research revealed that for the construction of 26 million $\mathrm{m}^{2}$ of floor spaces for residential buildings, a total of 2.3 million $\mathrm{m}^{2}$ of floor spaces were demolished. The new construction required a total volume of $7,253 \times 10^{4}$ tons of materials and energy and the demolition produced $4,137 \times 10^{4}$ tons of solid waste, $\mathrm{CO}_{2}$ and other air pollutants.

According to Fernandez (2007) residential buildings in China consumed approximately 1.6 and 7.7 times more materials respectively than commercial and industrial buildings due to more

Ding G (2013) 'Demolish or refurbish - Environmental benefits of housing conservation', Australasian Journal of Construction Economics and Building, 13 (2) 18-34 
internal sub-divisions. Fernandez (2007) further estimates that to meet the rising housing demand in China, China will need 512 million $\mathrm{m}^{3}$ of concrete each year, which means approximately 1.24 billion tons of cement. The extensive consumption of building materials to cope with the increasing housing demand has intensified with the high energy content embodied in the manufacturing processes of these materials. According to Yang and Kohler (2008) if embodied energy in building materials is taken into account, life cycle energy consumption of buildings in China can increase to over $45 \%$ of the national total energy consumption.

\section{The Project}

\section{Background}

The rapid growth in economic development and urbanization have contributed to the increasing demand for more new houses and thus placing historic houses under threat of demolition to make way for new construction. In response to the loss of many valuable heritage assets over the last decades, government and the public are now working to conserve what remains. Nevertheless, the need for old buildings to meet modern standards of environmental comfort and performance remains a potential economic deterrent to conservation. For this reason a research project to study the environmental performance of traditional Chinese housing and compare its performance with that of modern housing was undertaken jointly between universities in Sydney, Australia and Hangzhou, China.

The location selected for the project was Xiao He Zhi Jie (Little River Street) in a typical South China waterside town in Hangzhou metropolitan region. Xiao He Zhi Jie is part of a formerly thriving port town at the junction of the Xian He and Yuhang Tang Rivers. Xiao He Zhi Jie has a long history, beginning as early as the Tang Dynasty (618-907). Gradually, the area developed into a community during the late Qing Dynasty (1644-1911) and during the $19^{\text {th }}$ and early $20^{\text {th }}$ centuries, it became an important port with integrated warehouse, transportation, retail and service businesses. Most of the surrounding area has been redeveloped, but Xiao He Zhi Jie itself has been preserved by the Hangzhou municipal government as part of an extensive conservation program which began in 2002 and was completed in 2007 (see Figures 1 - 4). Nowadays Xiao He Zhi Jie has 120 households with 450 residents, half of whom are over 60 years old and have retired. The area now contains residential and retail sectors, and provides a setting for activities relating to traditional Chinese culture. Because some buildings were conserved while others were rebuilt in a traditional style but using modern materials, this site provided an excellent opportunity to compare traditional and modern construction versions of the same building configuration.

\section{The Buildings}

The style of the buildings is typical of late Qing Dynasty and reflects the living environment of relatively poor people. The houses featured weak stucco on masonry (usually brickwork) and roofs were clay tiled directly over timber-boarded ceilings with wood-framed windows and doors. The main structure consisted of framing poles (often built into the masonry) with horizontal poles as beams. Many upper floor external walls were timber framed and boarded, even between adjoining houses, with the pole framing partly exposed. Most of the buildings were one or twostorey high, combined in terraces or around courtyards. The buildings originally had no bathrooms or kitchens, and little acoustic or thermal insulation. The spaces between the houses were very narrow and contained little or no landscaping.

Ding G (2013) 'Demolish or refurbish - Environmental benefits of housing conservation', Australasian Journal of Construction Economics and Building, 13 (2) 18-34 


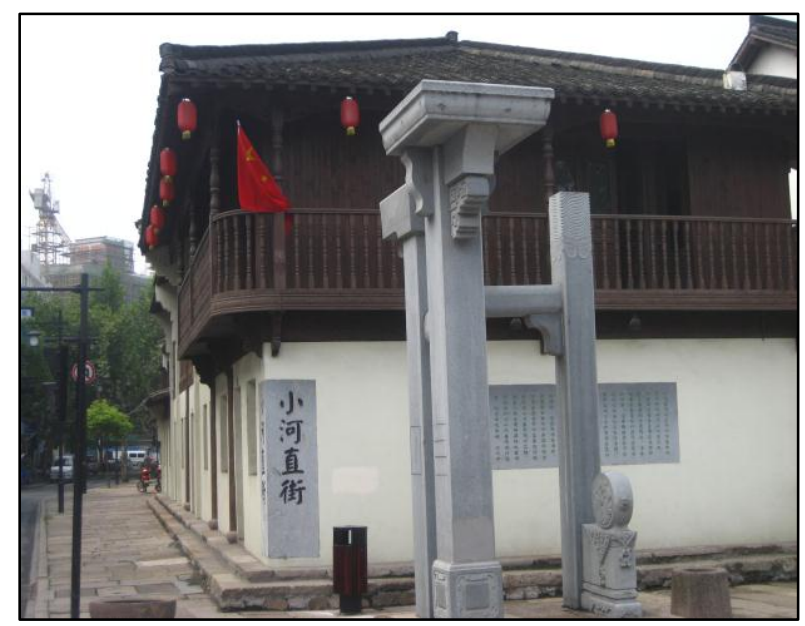

Figure 1 Entry logo of Xiao He Zhi Jie and the traditional timber construction upper floor

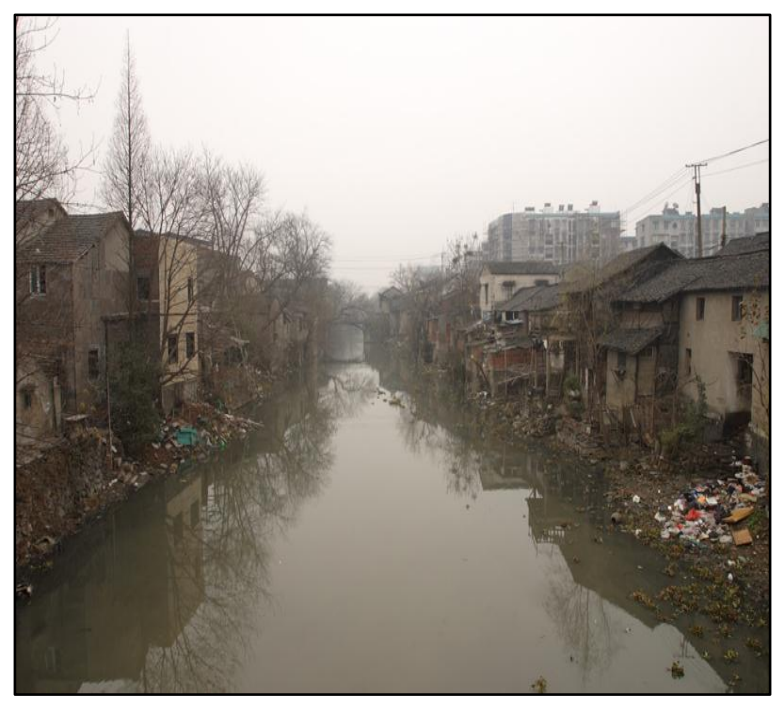

Figure 3 Dwellings along the Xiao He before renovation

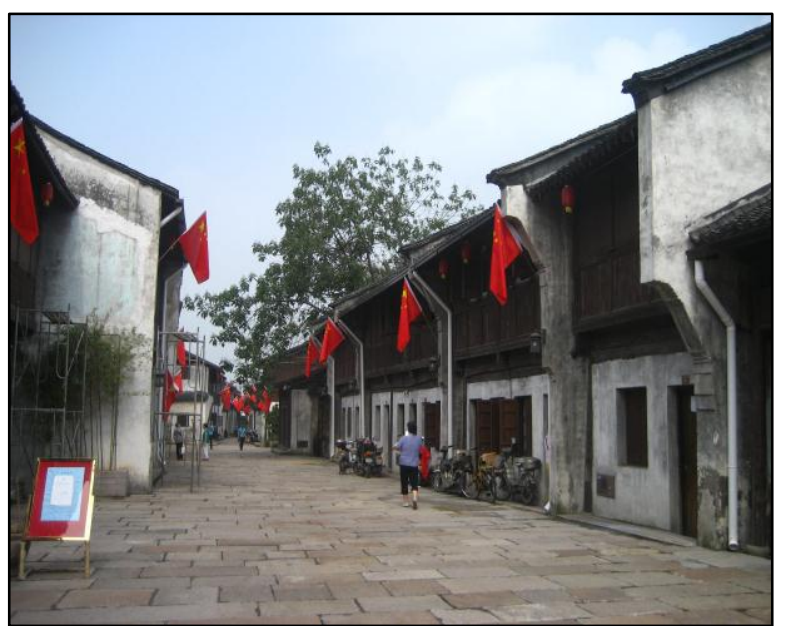

Figure 2 Dwellings at the square of Xiao He Zhi Jie

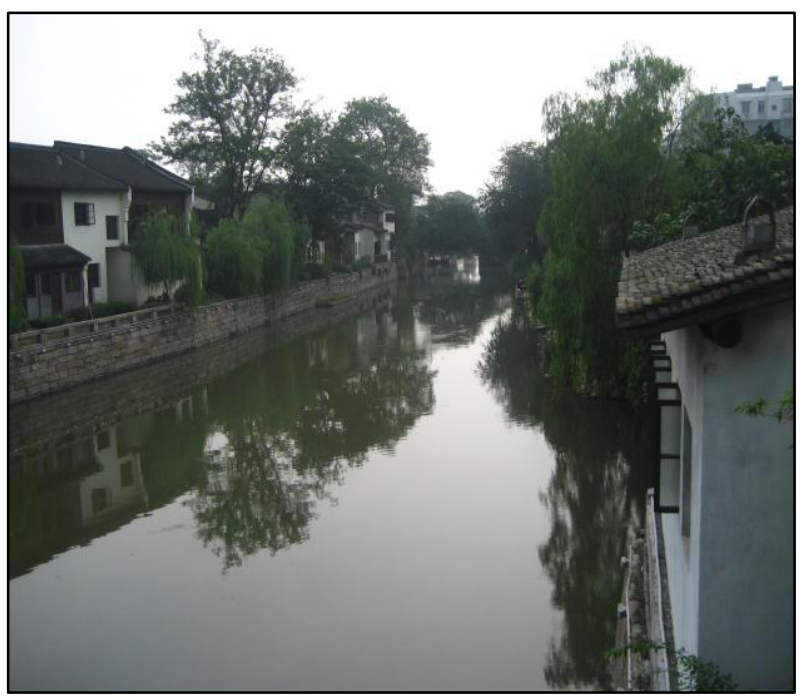

Figure 4 Dwellings along the Xiao He after renovation

\section{Research Methodology}

The purpose of the research was to examine whether the restored or rebuilt historic houses could perform as well as or provide similar living comfort and conditions to modern housing. A field study method was used to collect data for the study. The dwellings selected for the study were a mix of re-constructed buildings and old buildings that had been repaired. Even where the old structures were retained, the interiors of the houses were almost all modernized to some extent, with plasterboard wall and ceiling linings (often encasing the pole frame structure), and modern bathroom and kitchen facilities, usually located in a newly-built extension. Six historic dwellings in the Xiao He Zhi Jie, including two types of housing, were studied. The first type was restored housing where the buildings were brought back to the original style and condition using similar material. The second type was rebuilt housing where the buildings were newly built but in the same style as the original. A modern two-bedroom apartment in a new high-rise building in a nearby estate was also selected as a control building to test and compare performance. Table 1 summarizes the details of these houses.

Ding G (2013) 'Demolish or refurbish - Environmental benefits of housing conservation', Australasian Journal of Construction Economics and Building, 13 (2) 18-34 
The research was conducted in two stages. The first stage included a building and site assessment to identify the materials and methods of construction, and an occupancy assessment study of occupants for each dwelling. The second stage involved examining the embodied energy and $\mathrm{CO}_{2}$ content of the materials used, and collecting indoor climate data in these dwellings. Each of the selected dwellings had up to seven monitors located on walls and ceilings upstairs, downstairs, inside and outside measuring and recording the temperature and humidity at different locations around the dwellings, over a full annual climate cycle. The locations were chosen to cover a range of different orientations, positions within rooms, and locations relative to the river and streets. The monitors recorded the temperature and humidity in their vicinity every hour throughout the day and night. Occupants were also asked to keep a logbook of their activities that might affect the temperature and humidity, noting when they turned on heating or cooling equipment.

\begin{tabular}{|c|c|c|c|c|c|c|}
\hline $\begin{array}{l}\text { Project } \\
\text { ID }\end{array}$ & Type & $\begin{array}{l}\text { GFA } \\
\left(m^{2}\right)\end{array}$ & $\begin{array}{c}\text { No of } \\
\text { Bedrooms }\end{array}$ & $\begin{array}{l}\text { No of } \\
\text { Storeys }\end{array}$ & $\begin{array}{l}\text { Family } \\
\text { size }\end{array}$ & Construction \\
\hline A & Reconstructed & 55 & 2 & 2 & 3 & $\begin{array}{l}\text { RC ground \& timber upper } \\
\text { floor, rendered brick } \\
\text { lower/common (upper), } \\
\text { timber upper walls, timber \& } \\
\text { tiled roof }\end{array}$ \\
\hline B & Reconstructed & 53 & 2 & 2 & 2 & $\begin{array}{l}\text { RC ground \& timber upper } \\
\text { floor, rendered brick } \\
\text { lower/common (upper), } \\
\text { timber upper walls, timber \& } \\
\text { tiled roof }\end{array}$ \\
\hline C & Reconstructed & 44 & 2 & 1 & 3 & $\begin{array}{l}\mathrm{RC} \text { ground, rendered brick } \\
\text { walls, timber \& tiled roof }\end{array}$ \\
\hline D & Reconstructed & 58 & 2 & 2 & 2 & $\begin{array}{l}\text { RC ground \& timber upper } \\
\text { floor, rendered brick } \\
\text { lower/common (upper), } \\
\text { timber upper walls, timber \& } \\
\text { tiled roof }\end{array}$ \\
\hline$E$ & Conserved & 54 & 2 & 2 & 4 & $\begin{array}{l}\text { RC ground \& timber upper } \\
\text { floor, rendered brick } \\
\text { lower/common (upper), } \\
\text { timber upper walls, timber \& } \\
\text { tiled roof }\end{array}$ \\
\hline$F$ & Conserved & 91 & 3 & 2 & 3 & $\begin{array}{l}\text { RC ground \& timber upper } \\
\text { floor, rendered brick } \\
\text { lower/common (upper), } \\
\text { timber upper walls, timber \& } \\
\text { tiled roof }\end{array}$ \\
\hline $\mathrm{G}$ & New & 83 & 2 & $\begin{array}{l}\text { Single } \\
\text { storey in } \\
\text { 12-storey } \\
\text { building }\end{array}$ & 3 & $\begin{array}{l}\mathrm{RC} \text { floor \& ceiling, rendered } \\
\text { brick walls, tiled floor/wall to } \\
\text { bath/kitchen }\end{array}$ \\
\hline
\end{tabular}

Table 1 Summary of details for the dwellings

Data Analysis and Discussions

At the end of the study period the data collected for the project was analyzed. The analysis was divided into two parts. The first part focused on the embodied energy and $\mathrm{CO}_{2}$ emissions on a cradle-to-gate approach and the results were summarized in Tables 2 and 3, and Figure 5. The

Ding G (2013) 'Demolish or refurbish - Environmental benefits of housing conservation', Australasian Journal of Construction Economics and Building, 13 (2) 18-34 
second part concentrated on an analysis of indoor climate data which was collected for a 12month period and results are presented in Figures 6 and 7.

\section{Assessing Embodied Energy and CO2 emissions}

The model used to analyze energy consumption from cradle-to-gate for the study is based on the principle of energy accounting for buildings (Chen, Burnett \& Chau 2001; Yang \& Kohler 2008). The total energy considered in the study includes the energy uses in the extraction of raw materials, delivery of these materials to factories, manufacturing process of building materials, and finally delivery to sites. The energy use in various processes during construction on site was excluded. Since no drawings were available for the dwellings, site measurements were taken and converted into CAD drawings for later use in computer modeling. The initial step of the analysis involved quantifying materials used for each dwelling from the CAD drawings. In order to reduce the complexity of the analysis, the analysis focused on the key materials for the structural elements and basic finishes. The quantities were then multiplied by the energy intensities and the related $\mathrm{CO}_{2}$ emissions.

The literature review revealed that there was little information specific to China in this respect. As a result, the study has used a combination of data sources. A study from Tsinghua University has established a preliminary set of data of cradle-to-gate energy intensities for some building materials and were used for the study (Yang 2003). For the materials for which data were not available from China the analysis was based on the Inventory of Carbon and Energy Data developed by the University of Bath (Hammond \& Jones 2010). They are used to act as proxies for the study (Chen \& Zhang 2005; Gu \& Zhu 2006; Fridley, Zheng \& Zhou 2008; Deng, Prasad \& Osmond $2011 \mathrm{a} \& \mathrm{~b}$ ). It is noted that the data on energy intensities outside China are likely to differ from those that reflect Chinese production processes. They are used in the research as approximations in the calculation the inputs for the materials.

Table 2 and Figure 5 summarize the embodied energy and $\mathrm{CO}_{2}$ emissions for the dwellings and Table 3 presents percentage distribution of these elements. Tables 2 and 3 present the results in two major groups. One group contains the 6 dwellings with 4 reconstructed projects and 2 converted projects from Xiao He Zhi Jie. The other group consists of an apartment dwelling situated nearby. Refer to Table 1 for construction details for each project. Buildings from Xiao He Zhi Jie have brickwork for external and internal walls with reinforced concrete ground slab. Reinforced concrete was used for wall, floor and roof for the apartment block.

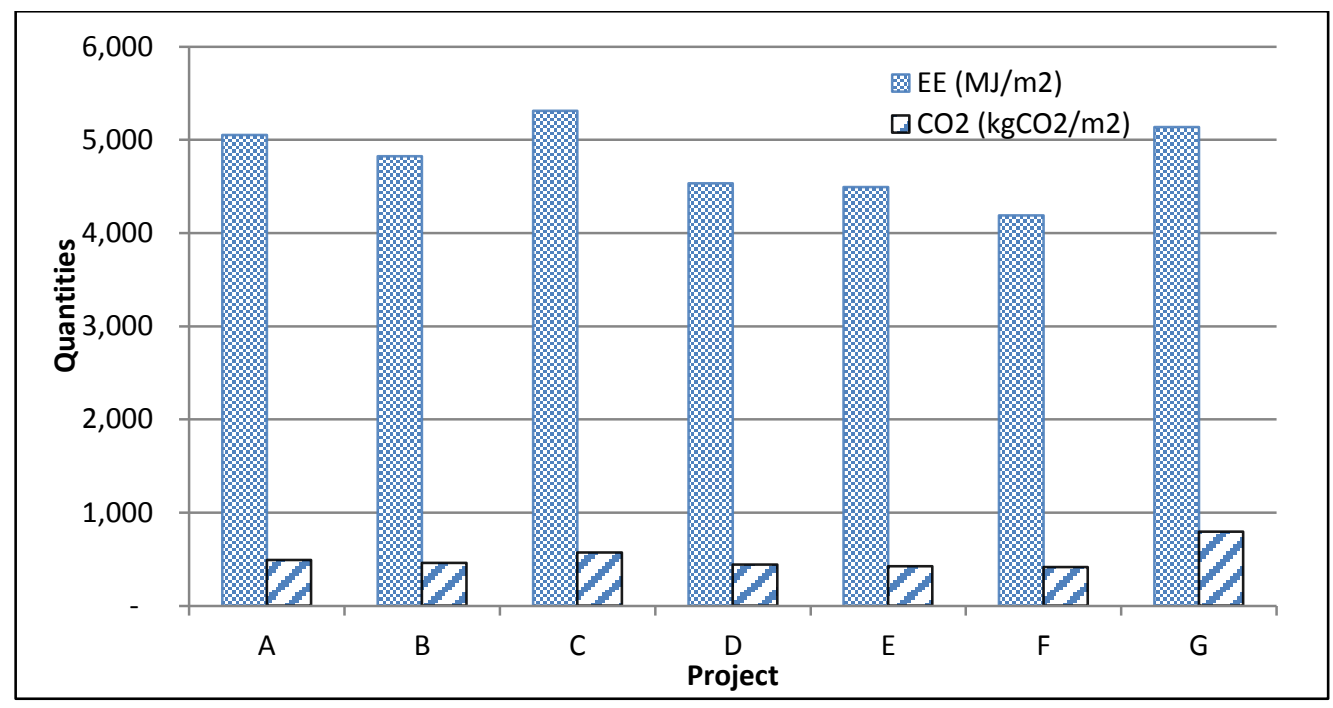

Figure 5 Summary of embodied energy and CO2 emissions per GFA

Ding G (2013) 'Demolish or refurbish - Environmental benefits of housing conservation', Australasian Journal of Construction Economics and Building, 13 (2) 18-34 


\begin{tabular}{|c|c|c|c|c|c|c|c|c|c|c|c|c|c|c|}
\hline \multirow{3}{*}{ Project ID } & \multicolumn{7}{|c|}{ Embodied Energy (MJ) } & \multicolumn{7}{|c|}{$\mathrm{CO}_{2}$ emissions $\left(\mathrm{kgCO}_{2}\right)$} \\
\hline & \multicolumn{4}{|c|}{ Reconstructed } & \multicolumn{2}{|c|}{ Conserved } & \multirow{2}{*}{$\begin{array}{c}\text { New } \\
\text { G }\end{array}$} & \multicolumn{4}{|c|}{ Reconstructed } & \multicolumn{2}{|c|}{ Conserved } & \multirow{2}{*}{$\begin{array}{c}\text { New } \\
\text { G }\end{array}$} \\
\hline & A & B & C & D & $\mathbf{E}$ & $\mathbf{F}$ & & A & B & C & D & $E$ & $\mathbf{F}$ & \\
\hline \multicolumn{15}{|l|}{ Structure } \\
\hline $\mathrm{RC}$ slab/roof & 49,556 & 44,694 & 70,577 & 52,542 & 44,553 & 87,654 & 222,635 & 8,178 & 7,375 & 11,646 & 8,670 & 7,352 & 14,464 & 36,738 \\
\hline $\mathrm{RC}$ walls & - & - & - & - & - & - & 145,532 & - & . & - & - & - & - & 24,015 \\
\hline $\begin{array}{l}\text { Brickwork } \\
\text { walls }\end{array}$ & 162,523 & 148,498 & 105,974 & 144,643 & 136,652 & 193,099 & 26,441 & 14,795 & 13,517 & 9,647 & 13,165 & 11,928 & 17,581 & 2,421 \\
\hline $\begin{array}{l}\text { Timber } \\
\text { structure }\end{array}$ & 20,130 & 23,485 & 13,420 & 23,485 & 20,130 & 33,550 & - & 570 & 665 & 380 & 665 & 570 & 950 & - \\
\hline Sub-Total & 232,209 & 216,678 & 189,971 & 220,670 & 201,335 & 314,303 & 394,608 & 23,543 & 21,557 & 21,674 & 22,500 & 19,850 & 32,996 & 63,174 \\
\hline \multicolumn{15}{|l|}{ Finishes } \\
\hline Floor/wall tile & 11,610 & 9,468 & 12,213 & 9,720 & 8,892 & 15,453 & 15,228 & 761 & 621 & 801 & 637 & 583 & 1,013 & 998 \\
\hline Roof tile & 14,586 & 12,656 & 20,469 & 14,866 & 12,259 & 24,050 & - & 1,032 & 896 & 1,449 & 1,052 & 868 & 1,702 & \\
\hline Timber & 6,173 & 5,603 & 1,678 & 6,073 & 6,542 & 9,226 & 973 & 175 & 159 & 48 & 172 & 185 & 261 & 28 \\
\hline Painting & 6,834 & 6,202 & 3,815 & 5,692 & 6,916 & 9,976 & 5,936 & 355 & 322 & 198 & 296 & 359 & 518 & 308 \\
\hline $\begin{array}{l}\text { Cement } \\
\text { render }\end{array}$ & 6,401 & 5,013 & 5,507 & 5,801 & 6,558 & 8,240 & 9,407 & 982 & 769 & 845 & 890 & 1,006 & 1,264 & 1,443 \\
\hline Sub-Total & 45,604 & 38,941 & 43,681 & 42,151 & 41,167 & 66,945 & 31,544 & 3,305 & 2,766 & 3,340 & 3,047 & 3,001 & 4,759 & 2,777 \\
\hline Total & 277,813 & 255,619 & 233,652 & 262,821 & 242,502 & 381,247 & 426,151 & 26,848 & 24,323 & 25,014 & 25,547 & 22,851 & 37,754 & 65,952 \\
\hline GFA $\left(m^{2}\right)$ & 55 & 53 & 44 & 58 & 54 & 91 & 83 & 55 & 53 & 44 & 58 & 54 & 91 & 83 \\
\hline Per GFA $\left(\mathrm{m}^{2}\right)$ & 5,051 & 4,823 & 5,310 & 4,531 & 4,491 & 4,190 & 5,134 & 488 & 459 & 568 & 440 & 423 & 415 & 795 \\
\hline
\end{tabular}

Table 2 - Summary of embodied energy and CO2 emissions 
From Table 2 and Figure 5, Project $C$ demonstrates the highest embodied energy per gross floor area (GFA), followed by Project $G$ of 5,310 and $5,134 \mathrm{MJ} / \mathrm{m}^{2}$ respectively. However with regards to $\mathrm{CO}_{2}$ emissions Project $\mathrm{G}$ gives the highest $\mathrm{CO}_{2}$ emissions followed by Project $\mathrm{C}$ with 795 and $568 \mathrm{kgCO}_{2} / \mathrm{m}^{2}$ respectively. Project $\mathrm{C}$ is a single storey building which has the biggest building footprint and requires longest external wall whilst Project $G$ has used reinforced concrete as the main structural elements which has the highest embodied energy and associated $\mathrm{CO}_{2}$ emissions. In addition as indicated in Project $\mathrm{F}$ total embodied energy reduces to the increase of GFA. Project $F$ has the highest embodied energy from Table 2 but has the lowest embodied energy and associated $\mathrm{CO}_{2}$ emissions per GFA due to larger total floor area as shown in Figure 5.

For both embodied energy and $\mathrm{CO}_{2}$ emission, structural elements contributed over $80 \%$ for all the dwellings in Xiao He Zhi Jie whilst over $90 \%$ for the unit in the apartment block (Table 3). Finishes constitute less than $20 \%$ and $10 \%$ respectively for the projects in Xiao He Zhi Jie and the apartment block. Structural elements are important in the initial embodied energy analysis as they mainly use high energy intensity materials such as reinforced concrete and bricks. They have long life span but high initial energy intensity. Materials for finishes constitute only a small fraction in the study. However they may become more important on a life cycle perspective as materials for finishes may require regular maintenance and replacement during the life of the building. The cumulative effects may outweigh the structural elements and be more important in the life cycle energy study.

The timber structure constitutes less than $10 \%$ for the dwellings in Xiao He Zhi Jie while there was no timber structure in the apartment block. For the finishes the majority of the embodied energy and $\mathrm{CO}_{2}$ emissions were embedded in the cement render and tiles to the floor, wall and roof for the unit in the apartment block. On average the unit in the apartment block with reinforced concrete structure consumes approximately $10 \%$ more embodied energy and releases $74 \%$ more $\mathrm{CO}_{2}$ than the dwellings in Xiao He Zhi Jie. A total of 1,653,654 MJ of energy and $162,337 \mathrm{kgCO}_{2}$ for a total floor area of $355 \mathrm{~m}^{2}$ were embedded in the dwellings in Xiao He Zhi Jie. If they are replaced with new buildings all this embodied energy will be lost and $\mathrm{CO}_{2}$ will be emitted to the atmosphere. If they are replaced with structural elements based around reinforced concrete these buildings will require approximately $10 \%$ more embodied energy and releasing approximately $75 \%$ more $\mathrm{CO}_{2}$ into the atmosphere.

\section{Assessing Indoor Climate}

Indoor climate is one of the most important factors contributing to user comfort. It is an area of concern in sustainability assessments of building performance in addition to energy efficiency and environmental load (Ding 2008; Sinopoli 2009). It is the state of mind that expresses satisfaction with the surrounding environment and is related to energy exchange between the body of occupants and the surrounding (Han et al. 2007). People feel comfortable if they feel neither warmer nor cooler than the surroundings and when the body functions and performs well (Frontczak \& Wargocki 2011). Achieving indoor comfort for most occupants of buildings or other enclosures is a goal of sustainable living and it is closely related to the building orientation and design, and the material used for the building. The indoor climate data contributes to the assessment of thermal comfort of a building and according to Frontczak and Wargocki (2011) thermal comfort is ranked by building occupants as of greater importance than visual and acoustic comfort and good air quality. Frontczak and Wargocki (2011) further state that factors influencing indoor comfort include characteristics of individual occupants, building-related issues and the outdoor climate.

Ding G (2013) 'Demolish or refurbish - Environmental benefits of housing conservation', Australasian Journal of Construction Economics and Building, 13 (2) 18-34 


\begin{tabular}{|c|c|c|c|c|c|c|c|c|c|c|c|c|c|c|}
\hline \multirow{3}{*}{$\begin{array}{l}\text { Project ID } \\
\text { Elements }\end{array}$} & \multicolumn{7}{|c|}{ Embodied Energy (MJ) } & \multicolumn{7}{|c|}{$\mathrm{CO}_{2}$ emissions $\left(\mathrm{kgCO}_{2}\right)$} \\
\hline & \multicolumn{4}{|c|}{ Reconstructed } & \multicolumn{2}{|c|}{ Conserved } & \multirow{2}{*}{$\begin{array}{c}\text { New } \\
\text { G }\end{array}$} & \multicolumn{4}{|c|}{ Reconstructed } & \multicolumn{2}{|c|}{ Conserved } & \multirow{2}{*}{$\begin{array}{c}\text { New } \\
\text { G }\end{array}$} \\
\hline & $\mathbf{A}$ & B & C & D & $\mathbf{E}$ & $\mathbf{F}$ & & A & B & C & D & $\mathbf{E}$ & $\mathbf{F}$ & \\
\hline \multicolumn{15}{|l|}{ Structure } \\
\hline RC slab/roof & 17.8 & 17.5 & 30.2 & 20.0 & 18.4 & 23.0 & 52.2 & 30.5 & 30.3 & 46.5 & 33.9 & 32.2 & 38.3 & 55.7 \\
\hline $\mathrm{RC}$ walls & - & - & - & - & - & - & 34.2 & - & - & - & - & - & - & 36.4 \\
\hline Brickwork walls & 58.5 & 58.1 & 45.4 & 55.0 & 56.3 & 50.6 & 6.2 & 55.1 & 55.6 & 38.6 & 51.6 & 52.2 & 46.6 & 3.7 \\
\hline Timber structure & 7.2 & 9.2 & 5.7 & 8.9 & 8.3 & 8.8 & - & 2.1 & 2.7 & 1.5 & 2.6 & 2.5 & 2.5 & - \\
\hline Sub-Total & 83.6 & 84.8 & 81.3 & 83.9 & 83.0 & 82.4 & 92.6 & 87.7 & 88.6 & 86.6 & 88.1 & 86.9 & 87.4 & 95.8 \\
\hline \multicolumn{15}{|l|}{ Finishes } \\
\hline Floor/wall tile & 4.2 & 3.6 & 5.2 & 3.7 & 3.7 & 4.1 & 3.6 & 2.8 & 2.5 & 3.2 & 2.5 & 2.5 & 2.7 & 1.5 \\
\hline Roof tile & 5.3 & 5.0 & 8.8 & 5.7 & 5.0 & 6.3 & - & 3.8 & 3.7 & 5.8 & 4.0 & 3.8 & 4.5 & - \\
\hline Timber & 2.2 & 2.2 & 0.7 & 2.3 & 2.7 & 2.4 & 0.2 & 0.7 & 0.7 & 0.2 & 0.7 & 0.8 & 0.7 & 0.1 \\
\hline Painting & 2.5 & 2.4 & 1.6 & 2.2 & 2.9 & 2.6 & 1.4 & 1.3 & 1.3 & 0.8 & 1.2 & 1.6 & 1.4 & 0.5 \\
\hline Cement render & 2.3 & 2.0 & 2.4 & 2.2 & 2.7 & 2.2 & 2.2 & 3.7 & 3.2 & 3.4 & 3.5 & 4.4 & 3.3 & 2.1 \\
\hline Sub-Total & 16.5 & 15.2 & 18.7 & 16.1 & 17.0 & 17.6 & 7.4 & 12.3 & 11.4 & 13.4 & 11.9 & 13.1 & 12.6 & 4.2 \\
\hline Total & 100 & 100 & 100 & 100 & 100 & 100 & 100 & 100 & 100 & 100 & 100 & 100 & 100 & 100 \\
\hline
\end{tabular}

Table 3 Percentage distribution of embodied energy and CO2 emissions 
Thermal comfort is measured by air temperature, relative humidity, radiant temperature and air velocity. However assessing all these parameters requires extensive resources. In considering the timeframe and nature of the research data collection, the research focuses on indoor air temperature and relative humidity only. The research aims at investigating and comparing performance of historical and modern residential dwellings based on the building materials used and their inherent capacity to provide comfort for users to investigate if an argument can be set up for building conservation rather than demolition. Data on air temperature and humidity are sufficient to provide a profile with respect to indoor comfort at this stage. The other parameters will be explored as part of future research.

The importance of air temperature and relative humidity in assessing thermal comfort has been confirmed by research reported in the literature. Sulaiman, Schellen and Hensen (2010). conducted an investigation of indoor climate of historic museum buildings and stated that in considering the overall indoor climate parameters, temperature and relative humidity are the most important as they are the dominant parameters in microclimate. Research by Yang and Zhang (2008) comparing naturally ventilated and air-conditioned buildings in five cities in China stated that in addition to air temperature humidity was found to have a significant effect on the thermal comfort. Another study by Indraganti and Rao (2010) investigating the effect of age, gender, economic groups and tenure on thermal comfort in naturally ventilated apartments in India supports this view and reveals that temperature and humidity have important effects on indoor thermal comfort level.

Indoor temperature and humidity may vary depending on the outdoor climate, building envelop, layout and materials used. Yang and Zhang (2008) in their research on thermal comfort in naturally ventilated and air-conditioned buildings suggest that the range of accepted temperatures in naturally ventilated buildings was $25-31.6^{\circ} \mathrm{C}$. The results indicate that occupants in naturally ventilated buildings seemed to be more tolerant of the high temperatures and were thermally comfortable in a wider range of temperature. Further Ge, Ding and Phillips (2012) suggest that in China around $23-28^{\circ} \mathrm{C}$ for summer and $18-25^{\circ} \mathrm{C}$ for winter is recommended. However, ASHRAE recommends thermal comfort with the summer temperature of $22.2-26.7^{\circ} \mathrm{C}$ and winter temperature $20-23.3^{\circ} \mathrm{C}$ (ASHRAE 2004). The thermal standards as developed by ASHRAE were based on theoretical analysis of human heat exchange and derive data from climate chamber experiments in a more controlled environment. These standards have been criticized as being inappropriate and concerns have been raised regarding disparities from the real-world situations (de Dear \& Brager 2002; Han et al. 2007; Yang \& Zhang 2008).

Mallick (1996) undertook a thermal comfort study of occupants living in urban housing in Bangladesh and the results indicate that people could endure high temperature and very high humidity for comfort. The work of de Dear and Brager (2002), Han et al. (2007) and Hussein and Rahman (2009) also suggest similar results - that people are able to adapt to the environment that they are used to. People can tolerate warmer or cooler temperature than predicted by comfort models and standards. In considering the variables that may impact on human comfort levels and their expectations, the indoor climate data for the study has been based on field study. The indoor climate for the project was examined by analyzing the data of indoor air temperature and relative humidity on a 12-month period from September 2010. As discussed before each dwelling had up to seven monitors located on walls and ceiling upstairs, downstairs, inside and outside to measure and record the temperature and humidity hourly over a full annual climate cycle. The records were also assessed against the official weather record of the meteorological station in Hangzhou city. Hangzhou is located in a subtropical monsoon climate with mild and moist weather. Average temperature in summer is $28.6^{\circ} \mathrm{C}$ and $3.8^{\circ} \mathrm{C}$ in

Ding G (2013) 'Demolish or refurbish - Environmental benefits of housing conservation', Australasian Journal of Construction Economics and Building, 13 (2) 18-34 
winter. The four seasons are distinct. Humidity for the city is high throughout the year around $70-80 \%$.

Once the climate data had been collected, they were checked for consistency. Temperature and humidity readings from the external monitors in comparable locations were checked against one another and compared with official climatic data. Then the data from the internal monitors was compared with that from the external monitors nearby, or with other internal monitors in the same or different houses. Apparent variations from the normal daily cycle were also checked against the logbooks to investigate possible reasons for the disparity. In assessing the logbooks for heating and cooling during the study period the records shown that all the dwellings in Xiao He Zhi Jie had similar use patterns. They used air conditioners for cooling during the summer from mid-July to mid-September but there was no record that heating was used during the winter months. However the logbook from the unit in the apartment block has shown more frequent use of heating and cooling throughout the study period, in particular during the hot weather in July/August and cold weather in December/January.

Figures 6 and 7 present the mean indoor temperature and humidity for the three types of dwellings for the research. The figures were also compared with the Hangzhou official climate data and the monitored outside temperature. Data collection and analysis have revealed good correlation between official climate data and the monitor readings, and good consistency between predicted and actual results and have indicated a consistency in the performance. At the same time, comparisons of readings from different types of construction, house orientation and monitor location have yielded interesting and less predictable outcomes.

The climate data collected between inside and outside of the historic dwellings at Xiao He Zhi Jie was reasonably consistent throughout the six dwellings used for the study. The data collected from different types of dwellings was also compared and the results have shown little difference between the temperature and humidity readings. Results for individual dwelling in Xiao He Zhi Jie indicate that:

- Indoor temperature was very similar but relative humidity fluctuated more;

- Indoor temperature fluctuated less than outdoor temperature;

- Wall temperature inside was generally higher than outside during winter months even without any heating;

- External wall temperature on the water side of the house was generally lower than that on the street site; and

- External wall temperature was lower on a downstairs wall than on an upstairs wall.

The mean indoor and outdoor temperature and humidity were established for the reconstructed and conserved dwellings in Xiao He Zhi Jie, and the dwelling in the apartment block. The data was also used to compare with Hangzhou official data and the results were presented in Figure 6 below.

Figure 6 demonstrates consistency in the profile in a 12 month period. In comparing with Hangzhou official data, the mean annual indoor temperatures for the dwellings were generally higher but their temperature range of $21.9-22.2^{\circ} \mathrm{C}$ was lower than that of the Hangzhou official data range of $24.9^{\circ} \mathrm{C}$. Monitors were also located outside each dwelling and in general the mean outdoor temperatures have revealed an average colder winter months and hotter summer months on the outside of each house with high temperature in the range of $7.05-32.12^{\circ} \mathrm{C}$. When comparing the climate data between the reconstructed dwellings using modern materials

Ding G (2013) 'Demolish or refurbish - Environmental benefits of housing conservation', Australasian Journal of Construction Economics and Building, 13 (2) 18-34 
and the conserved old dwellings in the area, there is little difference. The result shows that the conserved old dwellings appear to be slightly hotter in summer and slightly colder in winter than the reconstructed houses. However the temperature differences were only in the range of $0.05-$ $0.5^{\circ} \mathrm{C}$.

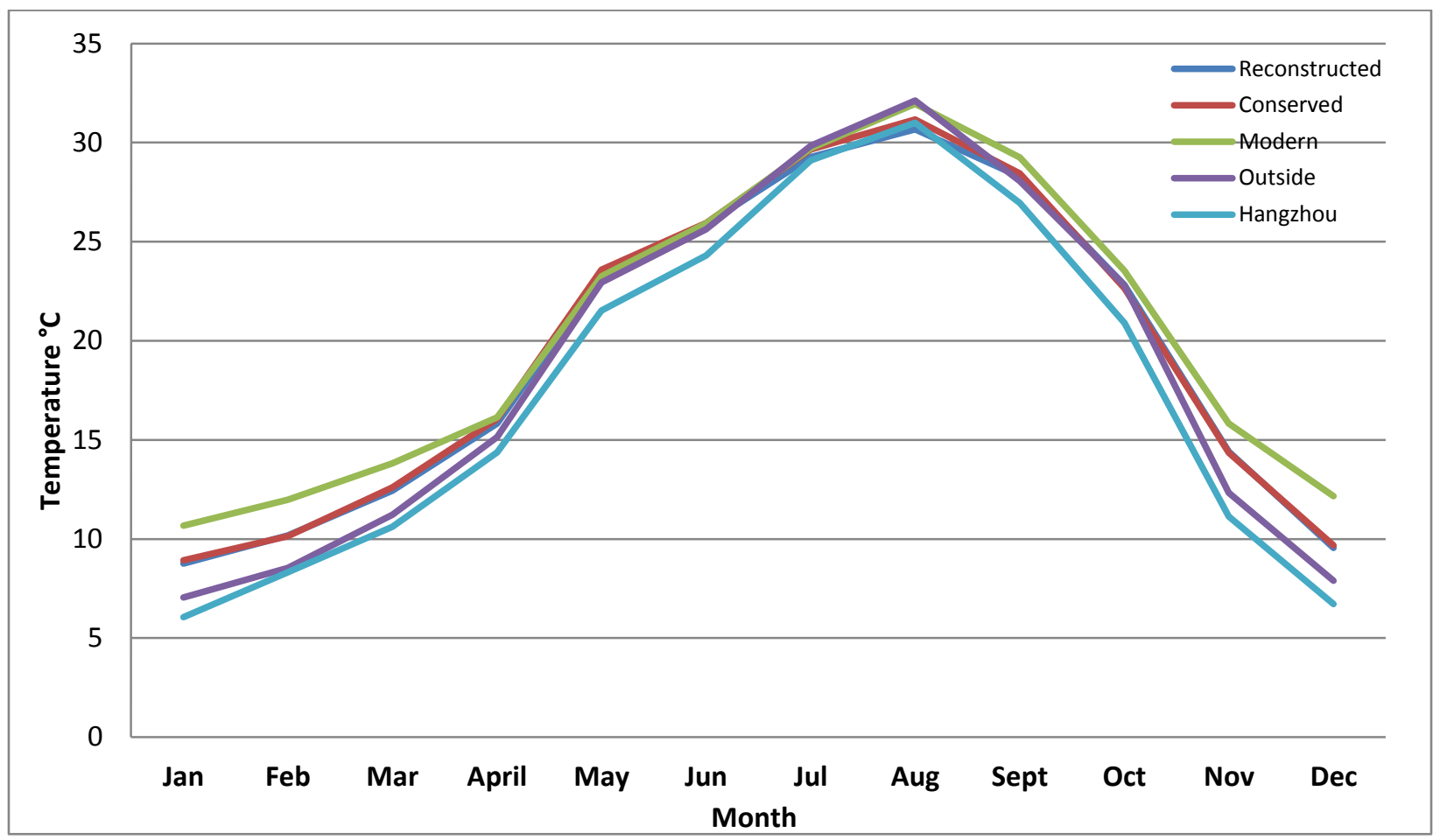

Figure 6 Summary of mean air temperature for a 12-month period

In comparing the dwellings in Xiao He Zhi Jie and the dwelling in the apartment block the temperature readings reveal that their indoor temperatures were very similar from April to July but generally higher in other months for the dwelling in the apartment block. The indoor temperature of the dwelling in the apartment block demonstrates warmer winter months by approximately $1.5-2.6^{\circ} \mathrm{C}$ and hotter summer months by approximate $0.05-1.3^{\circ} \mathrm{C}$. The warmer temperature during the winter months in the modern building could be explained by the frequent use of air conditioning for heating during these months. The results suggest that habits and level of tolerance to thermal comfort are factors contributing to user satisfaction too. Residents in Xiao He Zhi Jie have adapted to the cold weather and have used no to little heating during the winter months as compared with the occupants in the modern building. On the other hand, economic aspect may also be a factor as the households in Xiao He Zhi Jie are retirees or low income families. They will only use heating and cooling when absolutely essential. The findings correlate with the results in other published studies.

Figure 7 summarizes the mean indoor relative humidity for the subject dwellings for the research, compared with the monitor for outdoor relative humidity and the Hangzhou official data. The mean indoor relative humidity for the reconstructed and conserved dwellings was generally higher than the Hangzhou official data around the year by approximately $1.5-12 \%$. However the indoor relative humidity of the dwelling in the apartment block was lower than the Hangzhou data in the autumn months from September to November.

Ding G (2013) 'Demolish or refurbish - Environmental benefits of housing conservation', Australasian Journal of Construction Economics and Building, 13 (2) 18-34 


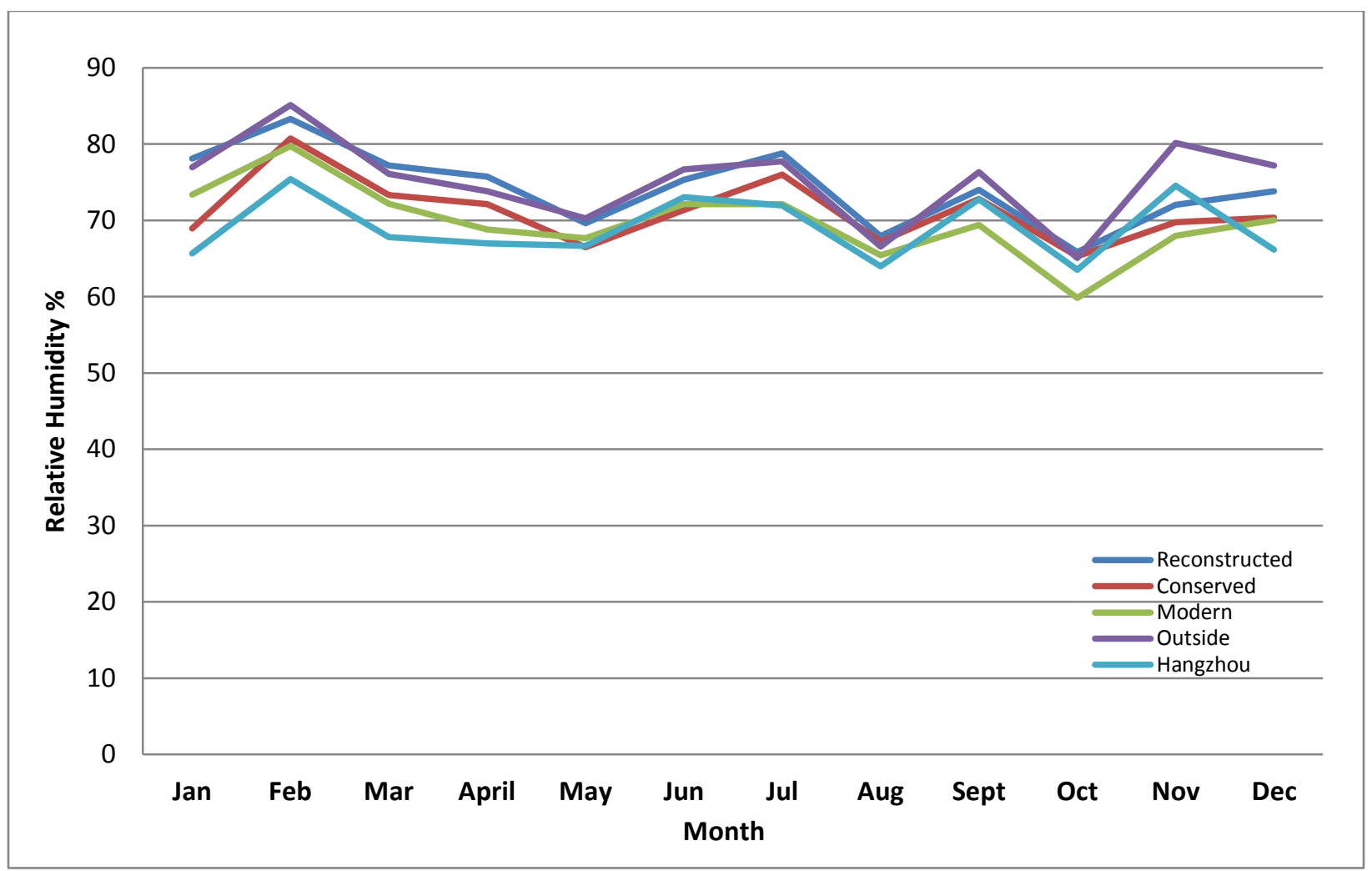

Figure 7 Summary of mean relative humidity for a 12 month period

On average the dwelling in the apartment block had a higher relative humidity range of $19.9 \%$ followed by the reconstructed houses with $17.4 \%$. The conserved houses had the lowest humidity range with $15.4 \%$. The outdoor relative humidity data have a very similar pattern to the reconstructed houses except November to December. In general the outdoor relative humidity recorded was higher for the entire study period with a higher range of $20.1 \%$. The conserved dwellings have demonstrated a lower relative humidity with a range of 65 to $81 \%$ than the reconstructed dwelling with a range of 66 to $83 \%$ for the 12-month period. The data demonstrate a dryer and less fluctuating indoor environment for the conserved dwellings than the reconstructed dwellings in the same region. The higher relative humidity of the reconstructed houses may be due to the location next to the river of some of these dwellings.

However the dwelling in the apartment block has demonstrated a lower indoor relative humidity than the dwellings in Xia He Zhi Jie with a range of 60 to $80 \%$. It appears that on average the dwelling in the apartment block has lower relative humidity during the autumn/winter months than during the other months of the year. It correlates with the higher indoor temperature during these months as demonstrated in Figure 7. Similarly, the lower relative humidity of the dwelling in the apartment block could be explained with more frequent use of air conditioning for heating and cooling.

\section{Conclusions}

This paper compares performance between historic and modern buildings in order to investigate an argument for conservation rather than demolition. If historic buildings perform as well as modern buildings, then conservation will be an important consideration to achieve the goal of ecologically sustainable development in the construction industry. Building conservation will

Ding G (2013) 'Demolish or refurbish - Environmental benefits of housing conservation', Australasian Journal of Construction Economics and Building, 13 (2) 18-34 
achieve saving in terms of embodied energy, virginal building materials and reducing the negative impact on the environment in the form of emissions and waste.

This paper assessed and compared embodied energy and $\mathrm{CO}_{2}$ emissions on a cradle to gate approach for these dwellings in the research. The results reveal that majority of the energy and associated $\mathrm{CO}_{2}$ were embedded in the structure of the buildings. This means that consideration should be taken to reuse existing buildings to lessening the environmental impacts of new construction. This requires considerably less energy than demolition of existing buildings, manufacture, transport, and installation of new materials. It also conserves the embodied energy in the existing buildings. The results have demonstrated a strong and valid argument that building conservation has significant impact on the resource consumption. The paper also assessed indoor climate through monitoring and recording indoor air temperature and relative humidity for a 12-month period. The data from the monitors were also validated by a good correlation between official data, and the monitor readings and comparisons of readings from different types of construction and monitor locations.

When data from different dwellings were compared, the research has shown little difference between the temperature and humidity readings in the conserved old buildings, those in the houses that have been rebuilt using modern materials and the modern building. This indicates that, at least for the construction types encountered in the study, buildings of conventional modern construction may perform only marginally better than historic buildings. This has provided another argument for building conservation rather than demolition. The study has demonstrated that preserving existing housing stocks is an ideal and feasible solution in addressing the global challenges of climate change and energy conservation.

There is little evidence from the research and from the literature suggesting that old buildings perform worse than modern buildings. These buildings are valuable assets in the cultural, environmental and scientific progress of humankind, and their conservation provides an important mean of conserving the finite natural resources and minimizing the load on the environment. Demolishing these buildings may seem to be a fast and efficient solution to improve the living environment and user satisfaction level for occupants as well as creating economic activities but the long term impact on the environment and the depletion of finite resources cannot be neglected. These issues may only be resolved if comprehensive investigations and comparisons are undertaken to these buildings before starting to demolish them. In addition the performance of these buildings can be improved if they are maintained and updated in more efficient and effective ways.

\section{References}

ASHRAE (2004) Thermal environmental conditions for human occupancy, American Society of Heating, Refrigerating and Air-conditioning Engineers, Standard 55

Boardman, B., Darby, S., Killip, G., Hinnells, M., Jardine, C.N., Palmer, J. \& Sinden, G. (2005) 40\% House, Environmental Change Institute, Oxford, UK

Bromley, R.D.F., Tallon, A.R. \& Thomas, C.J. (2005) 'City centre regeneration through residential development: contributing to sustainability', Urban Studies, 42 (13), 2407-2429

Bullen, P.A. (20070 'Adaptive reuse and sustainability of commercial buildings', Facilities, 25 (1/2), 20-31

Cabinet Office (2000) Resource productivity: Making more with less, Performance Innovation Unit, Cabinet Office, London

Ding G (2013) 'Demolish or refurbish - Environmental benefits of housing conservation', Australasian Journal of Construction Economics and Building, 13 (2) 18-34 
Chen, T.Y., Burnett, J. and Chau, C.K. (2001) 'Analysis of embodied energy use in the residential building of Hong Kong', Energy, 26, 323-340

Chen, Y. \& Zhang, T. (2005) 'Analysis of material flow of residential buildings in Beijing', Journal of Architecture and Civil Engineering, 22 (3), 80-83

de Dear, R.J. \& Brager, G.S. (2002) 'Thermal comfort in naturally ventilated buildings: revisions to ASHRAE Standard 55', Energy and Buildings, 34, 549-561

Deng, W., Prasad, D., Osmond, P. and Li, F.T. (2011a) 'Quantifying life cycle energy and carbon footprints of China's residential small district', Journal of Green Building, 6 (4), 96-110

Deng, W., Prasad, D. K. and Osmond, P.W. (2011b) 'Application of "streamlined" material input per service unit concept to small residential districts in China', Journal of Industrial Ecology, 15 (6), 967-979

Ding, G.K.C. (2008) 'Sustainable construction - The role of environmental assessment tools', Journal of Environmental Management, 86 (3), 451-464

Fernandez, J.E. (2007) 'Resource consumption of new urban construction in China', Journal of Industrial Ecology, 11 (2), 99-115

Fridley, D.G., Zheng, N. \& Zhou, N. (2008) Estimating total energy consumption and emissions of China's commercial and office buildings, Environmental Energy Technologies Division, Berkeley, CA, USA

Frontczak, M. \& Wargocki, P. (2011) 'Literature survey on how different factors influence human comfort in indoor environments', Building and Environment, 46, 922-937

Ge, J., Ding, G. \& Phillips, P. (2012) 'Sustainable housing - a case study of heritage building in Hangzhou China', Proceedings of $18^{\text {th }}$ Annual Pacific-Rim Real Estate Society Conference, Adelaide, Australia, 15-18 January

Gu, D.J. \& Zhu, Y.X. (2006) 'Life cycle assessment for China building environment impacts', Science and Technology, Journal of Tsinghua University, 46 (12), 1953-1956

Hammond, G.P. \& Jones, C.I. (2011) Inventory of carbon and energy Version 2.0, Sustainable Energy Research Team, University of Bath, UK

Han, J., Zhang, G., Zhang, Q., Shang, J., Liu, J., Tian, L., Zheng, C., Hao, J., Lin, J., Liu, Y. \& Moschandreas, D.J. (2007) 'Field study on occupants' thermal comfort and residential thermal environment in a hot-humid climate of China', Building and Environment, 42, 4043-4050

Hussein, I. \& Rahman, M.H. (2009) 'Field study on thermal comfort in Malaysia', European Journal of Scientific Research, 37 (1), 127-145

Indraganti, M. \& Rao, K.D. (2010) 'Effect of age, gender, economic group and tenure on thermal comfort: a field study in residential buildings in hot and dry climate with seasonal variations', Energy and Buildings, 42, 273-281

International Energy Agency (2009) World energy outlook 2010, IEA, Paris

Ireland, D. (2008) New tricks with old bricks, The Empty Homes Agency, London

Jackson, R. and Judson, E.P. (2011) 'Are we wasting embodied energy? Time to change - An Australian perspective', Proceedings of the 17th ICOMOS General Assembly, 27 Nov-2 Dec, Paris, 1083-1095

$\mathrm{Li}, \mathrm{B}$. and Yao, R. (2012) 'Building energy efficiency for sustainable development in China: Challenges and opportunities', Building Research \& Information, 40 (4), 417-431

Ding G (2013) 'Demolish or refurbish - Environmental benefits of housing conservation', Australasian Journal of Construction Economics and Building, 13 (2) 18-34 
Mallick, F.H. (1996) 'Thermal comfort and building design in the tropical climate', Energy and Buildings, 23, 161-167

Mao, R. (2007) 'Preservation's essential role in fighting climate change' (http://www.preservationnation.org/sustainable.stewardship) Logon: 12/2/2013

Mickaityte, A., Zavadskas, E., Kaklauskas, A. \& Tupenaite, L. (2008) 'The concept model of sustainable buildings refurbishment', International Journal of Strategic Property Management, 12, 53-68

Power, A. (2008) 'Does demolition or refurbishment of old and inefficient homes help to increase our environmental, social and economic viability?' Energy Policy, 36, 4487-4501

Sustainable Development Commission (2006) Stock take: delivering improvements in existing housing, Sustainable Development Commission, London.

Silberman, N. (2011) 'Heritage as a driver of development? Some questions of cause and effect', Proceedings of the 17th ICOMOS General Assembly, 27 Nov-2 Dec, Paris, 55-57

Sinopoli, J. (2009) 'How do we measure the performance of a building? Smart Buildings, LLC' (http://www.smart-buildings.com/pdf/howdo we measure0809.pdf) Accessed 15/9/2012

Sulaiman, R., Schellen, H.L. \& Hensen, J.L.M. (2010) 'Pilot study on indoor climate investigation and computer simulation in historical museum building: Amerongen Castle, the Netherlands', Journal of Design and Built Environment, 7, 75-94

Yang, W. and Kohler, N. (2008) 'Simulation of the evolution of the Chinese building and infrastructure stock', Building Research \& Information, 36 (1), 1-19

Yang, X. M. (2003) Quantitative assessment of environmental impact on construction during planning and designing phases, Master's Thesis, Tsinghua University, Beijing, China (in Chinese).

Yang, W. \& Zhang, G. (2008) 'Thermal comfort in naturally ventilated and air-conditioned buildings in humid subtropical climate zone in China', International Journal of Biometeorology, 52 (5), 385-398 